\title{
SHORT-TERM FORECAST OF PASSENGER AIR TRANSPORT. RZESZOW INTERNATIONAL AIRPORT IN JASIONKA - EMPIRICAL STUDY
}

\begin{abstract}
In recent years one can observe a significant increase in the number of passengers using air transport. There is a continual struggle between different airlines across the globe resulting in the rapid development of these services. Services market in air transport requires continuous research and conducting statistical analyzes.

The article attempts to develop a short-term forecasts of air passenger transport. The forecast will be developed on the basis of the time series. The data covers the period from January 2007 to May 2012. It is collected on a monthly basis. For forecasting it was used the model of exponential smoothing and homologous period trend.

The forecasting and modeling will be performed by using Statistica 9.1. PL.
\end{abstract}

\section{INTRODUCTION}

The Polish aviation market as a part of the communal market is facing the challenge of effectively satisfying public demand for air travel. This applies not only to the capacity of airport infrastructure but also its effective insertion into the Polish, and especially the European transport system.4 Polish airports are currently experiencing real growth. This is due to the world's fastest passenger traffic growth. Only in 2006 did one-third more passengers pass through the airport than in 2005. At the same time passenger traffic at airports across Europe grew by only 7 percent. The biggest changes affecting the volume and structure of demand for transport take place in the field of technology and innovative transport technologies in the structure and in the sphere of production and way of life of society. $^{5}$

Opening up the market to new carriers, greater competition and falling prices of the tickets make that passengers are increasingly opting for airlines. And it is going to be like this for the next few years provided that the number of new airports will increase and the old will be upgraded. 6 There is, therefore, a need to predict the future in the form of passenger forecasts for the current civil airports which, while at least a little will give an

\footnotetext{
${ }^{1}$ Ph.D., Eng., Jacek Brożyna, The Faculty of Management, Rzeszow University of Technology, Rzeszow.

${ }^{2}$ Ph.D., Katarzyna Chudy-Laskowska, The Faculty of Management, Rzeszow University of Technology, Rzeszow.

${ }^{3}$ Ph.D., Maria Wierzbińska, The Faculty of Management, Rzeszow University of Technology, Rzeszow.

${ }^{4}$ Strategia rozwoju transportu do 2020 roku (z perspektywa do 2030 roku) projekt, Ministerstwo Infrastruktury, Warszawa 2011, s. 54.

${ }^{5}$ Burnewicz J., ,, Wizja struktury transportu oraz rozwoju sieci transportowych do roku 2033 ze szczególnym uwzględnieniem docelowej struktury modelowej transportu”, Uniwersytet Gdański Tom II s. 33.

${ }^{6}$ Wilecki P.; ,,Polskie lotniska czekajq na inwestycje”, Transport i spedycja nr.2 2008.
} 
overview of the future. Therefore, one should emphasize the importance of traffic forecasts that are the basis not only for financial planning, but also investment - infrastructure. For example, the airport capacity planning requires long-term forecasts of the aircraft traffic. The expected number of operations determines the number of runways, taxiways and the number of sleeves. The number of different categories of passengers (e.g. arriving, departing, in transit) determines the bandwidth requirements of the terminal. What is more, the traffic also affects other elements such as infrastructure, aviation Cargo and other non-aviation services. The classic approach to generate long-term forecasts is to use statistical methods of time series and econometric models to extrapolate the observed growth patterns (gravity models and analysis of variants). It is important to remember about the relationship between the number of flight operations and the demand for the transport of passengers. Changing the number of passengers will result in the first place in the change of coefficient of filling up the aircraft and as a result it will influence on the variety of the fleet. Traffic forecasting by using the (regional) traffic models is to determine the demand for air transport in the region.

More detailed modeling includes the following models: a choice of access means to the area of the airport and air service forecasting models (which are included as exogenous variables). Another important issue is the seasonality of air transport. It is necessary to monitor changes in traffic volumes in the individual months of the year and day of the month. The main output traffic forecasts are: the number of passengers (existing traffic, traffic diversion to other airports, other transport, generated traffic) shipping charges (if applicable), travel distribution by source / destination (for source-destination traffic and connecting traffic), the number of flight operations, the average number of passengers or cargo units for a given type of operation, the average level of occupancy or commercial capacity, average maximum takeoff weight of an aircraft, appropriate for the type of operation or complete forecast, if it comes to one type of flight operation. ${ }^{\text {? }}$

The Carpathian region is characterized by low socio - economic development. The developed rankings inform that both in terms of competitiveness and innovation this region occupies the penultimate position. ${ }^{8}$ One of the major factors causing the growth of innovation in this region may be the development and modernization of transport infrastructure. It is believed that a new challenge for the Podkarpackie region's dynamic development is aviation market.

The aim of the research is an attempt to draw up a short-term outlook for the transport of passengers at Rzeszow Airport - Jasionka. Hence the Airport is the object of the research, and the subject is the passenger transport. Research period are the years 2007 2012 in the month section. The source of information is the website of Rzeszow Airport Jasionka.

In order to calculate the forecasts the appropriate test procedures were applied. The selection was made through the appropriate methods of analysis of time series graphs of the collected statistical data. The study used a package of Excel and Statistica Pl.

\footnotetext{
${ }^{7}$ Niebieska księga - Nowe wydanie. Sektor transportu lotniczego, Wrzesień 2008 s. 15-16.

${ }^{8}$ Chudy K., Wierzbińska M.,(2003) Ocena zróżnicowania powiatów województwa Podkarpackiego ze względu na infrastrukture społecznq, Wydawnictwo Politechniki Rzeszowskiej, Rzeszów oraz Chudy K., Wierzbińska M., „Zróżnicowanie województw pod względem infrastruktury transportowej w Polsce - wyniki badań”, Zeszyty Naukowe Politechniki Rzeszowskiej, „Zarządzanie i Marketing”, z.18, Oficyna Wydawnicza Politechniki Rzeszowskiej, Rzeszów 2011, s. 305-314.
} 


\section{THE CHARACTERISTICS OF AIRPORT IN JASIONKA}

In Poland there are eight airports now belonging to the Trans-European Transport Network TEN-T ${ }^{9}$ and one of them is the Airport Rzeszów-Jasionka. ${ }^{10}$ The history of the Carpathian currently the only civilian airport began in 1940 form the construction of the runway in the village Jasionka (located $10 \mathrm{~km}$ north of Rzeszow). In the 70-ies of the last century, the airport flourished serving over 100 thousand passengers per year and receiving in 1974 the rank of an international airport. After the crisis of the 90- ies Rzeszow airport again began to flourish, in 2011 to serve nearly 0.5 million passengers (an increase of $500 \%$ over 6 years) and take in this regard 7 th place in Poland.

Rzeszow Airport - Jasionka is the farthest to the southeast airport in Poland. It has the second-longest runway in the country (out of civilian airports) and is equipped with modern navigation equipment with global standards so that even large aircraft can land here in difficult conditions ${ }^{11}$. The airport area covers over 650 ha and its immediate surroundings are flat and has no natural barriers, and the number of flying days is the largest in the country. No concentration of other civil airports near Rzeszow (the nearest in Cracow, Katowice and Warsaw) make it interesting for airline passengers who want to transport passengers (a large part of them are immigrants) who often have to commute hundreds of kilometers to other airports. The airport by using its chance has made large investments modernizing and extending the runway, building another apron and taxiway and putting into use in 2012 a new terminal. The funds for the modernization of airports in large part have been obtained from various European Union programs:

- From the European Regional Development Fund under the Regional Operational Programme of Podkarpackie Voivodeship for the years 2007-2013 and their value was 4 mln 720 thous. 180,00 PLN, of which 3 million 288 thous., 650,00 PLN from the European Regional Development Fund "We are investing in the development of Podkarpackie Voivodeship".

- 104476276.83 PLN within the project "Rzeszow Airport - Expansion and modernization of airport infrastructure", of which the amount of subsidies was 42549228.60 PLN.

- 102728011.37 PLN in the framework of the project "Rzeszow Airport - Construction of a new passenger terminal," from which the amount of subsidies was 37694 48641 PLN.

\footnotetext{
${ }^{9}$ TEN (Trans-European Network) a European Union aid program functioning as a separate budget line of the EU budget. This program is aimed at supporting the development of trans-European transport network (TEN$T)$, Energy (TEN-E), and telecommunications (e-TEN). Within the framework of the TEN-T budget can be funded large-scale projects of common interest whose main objective is the development of a common market of the European Union by supporting: the sustainable development of transport networks, interoperability of the transport system and its consistency with other modes of transport, the environment and increase safety standards, increase employment and stimulate economic development in peripheral regions need support, improve communication with the island regions of the central part of the European continent.

${ }^{10}$ DIAGNOZA POLSKIEGO TRANSPORTU, Stan w 2009 roku, Załącznik 1 do Strategii Rozwoju Transportu, Ministerstwo Infrastruktury, Warszawa 2011,s. 17.

${ }^{11}$ Raport o stanie zagospodarowania przestrzennego województwa podkarpackiego, Część III Infrastruktura Techniczna, Rzeszów 2009, s. 17.
} 
Nowadays there are regular flights to most airports in Poland, some European countries and Transatlantic flights to New York from the Rzeszów - Jasionka airport. Some of the carriers are: PLL „LOT”, Ryanair, Lufthansa and OLT Express.

\section{PRESENTATION AND ANALYSIS OF STATISTICAL MATERIAL}

The starting point to prepare a forecast for passenger traffic is collecting historical data concerning air traffic in a given area and choice of proper forecasting method ${ }^{12}$

The data includes periods from January 2007 to May 2012. It is collected in monthly intervals. It is characterized with growing trend and multiplicative fluctuations. Due to the airport's expansion (opening of the New Terminal in April 2012), models that allow taking into account increase in growing trend in the prepared prognosis were used for forecasting.

Figure 1. Number of passengers in the Rzeszów - Jasionka Airport

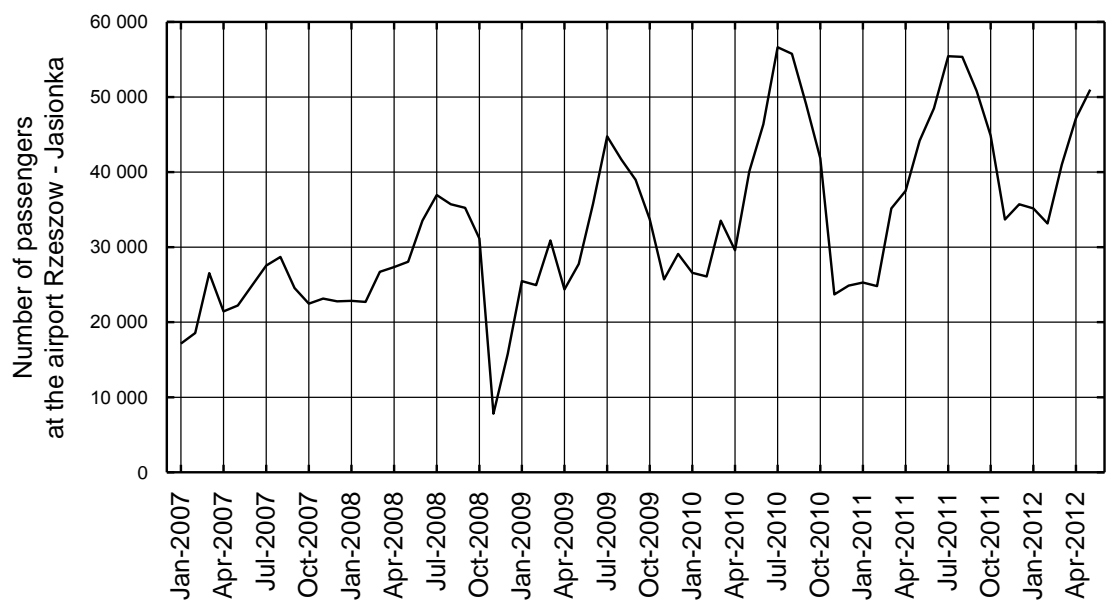

Source: own study.

Intensification of passenger traffic begins in summer months, increased passenger activity is visible from April, while in July the amount of traffic is at a maximum. It is a vacation and holiday season. At that time there are many kinds of promotions, used eagerly by customers, especially when booking a flight in advance one can save financial means and travel time. Airlines become more and more competitive means of transport and flight prices can be much lower than railway or bus transport. The smallest passenger traffic in the airlines is seen in winter months: November, December and February. At that time there is also a visible an increase in passenger traffic in December, which is caused by passengers travelling in the holiday time.

By means of the ANOVA - Kruskal - Wallis test it was checked if the average passenger transfer quantity in individual months differs significantly statistically. Significance level $\alpha=0,05$ was used for research. According to the conducted test there is a significant statistical difference in average passenger transfer quantity in individual months

\footnotetext{
${ }^{12}$ Niebieska księga Nowe wydanie Sektor transportu lotniczego, September 2008 p. 16.
} 
$\mathrm{p}<\alpha(\mathrm{p}=0,0066)$. Average passenger transfer quantity levels in individual months are presented in figure 2.

Figure 2. Average passenger transfer quantity in individual months in the Rzeszów Jasionka Airport

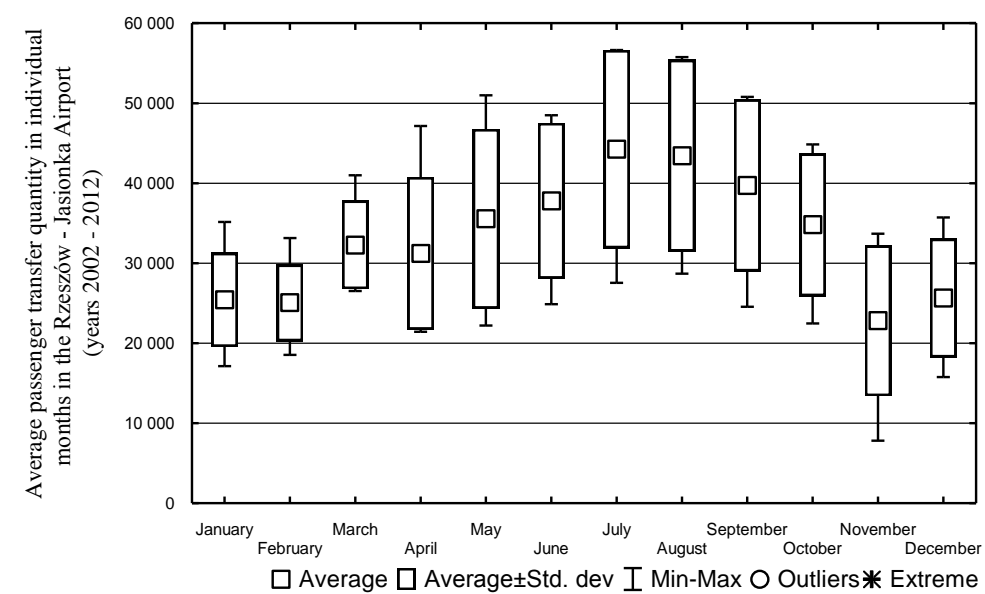

Source: own study.

When creating a forecast one has to take into account the fact that in April 2012 a new airport terminal was opened, which may cause an increase in passenger traffic.

\section{RESEARCH PROCEDURES}

To forecast number of passengers in the Rzeszów - Jasionka Airport two methods were used: exponential smoothing ${ }^{13}$ and homologous period trend estimation. These methods take into account in their procedures the increase in fluctuations amplitude in individual periods and they can be used if the output data is characterized with developing tendency, periodic and accidental fluctuations.

\subsection{Prognoses obtained by means of exponential smoothing}

The essence of exponential smoothing is based on the fact that time series of forecast variable is smoothed by means of weighted moving average whereas weights are defined according to the exponential function. The forecast is based on the weighted average of current and historical values of the series ${ }^{14}$. Exponential smoothing can be based on different models, proper for type of the analyzed components of the analyzed time series.

To define seasonal delays in model one uses correlogram i.e. function graph of autocorrelation series. According to the correlogram the seasonal delays amount to 12 . On each twelfth observation there are maximal and minimal values in series.

\footnotetext{
${ }^{13}$ Grubb H., Mason A., ,Long lead-time forecasting of UK air passengers by Holt-Winters methods with damped trend", International Journal of Forecasting 17 (2001) p.71-82.

${ }^{14}$ Aczel A.D., Statystyka w zarzadzaniu, Wydawnictwo Naukowe PWN, Warszawa 2000.
} 
Figure 3. Function of cargo transport autocorrelation

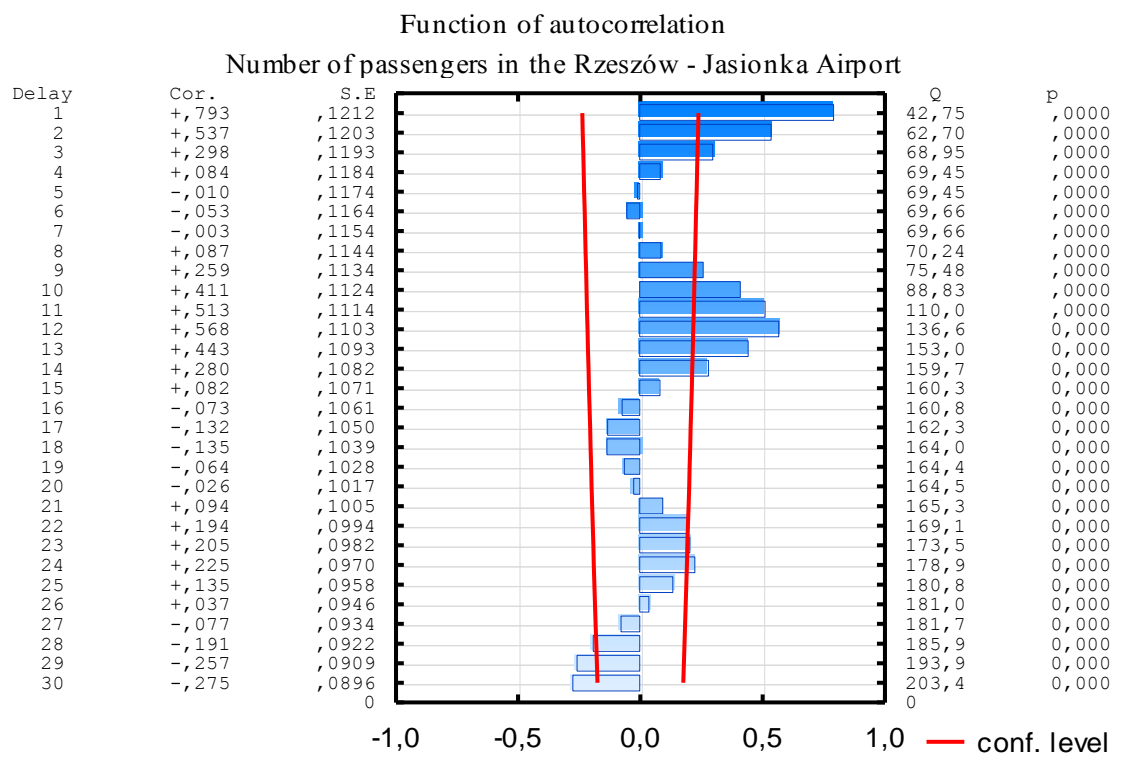

Source: Own study.

In the next stage the exponential smoothing model with exponential trend and additive and multiplicative fluctuations will be estimated. Seasonal distribution points that fluctuations are additive, but in last two years the fluctuation amplitude significantly increases, not taking trend into account. This is why two models will be estimated and the one with fewer errors ${ }^{15}$ will be used as a forecast model.

In the case of exponential smoothing models the key issue is choice of model parameters values. In the subject literature there are some ways for making choice of parameters $^{16}$. If individual components are changing quickly, then it is thought that smoothing parameters values should be set on the level close to one, in other case on the level close to zero. Parameters values can also be selected by experiment, minimizing chosen errors.

\footnotetext{
${ }^{15}$ Set of errors among which the most precise model was chosen is presented in Table 1.

${ }^{16}$ Gardner E.S. "'Exponential smoothing”, The state of the art. Journal of Forecasting 4, 1-28,1985
} 
Table 1 Comparison of errors for chosen models of exponential smoothing

\begin{tabular}{|c|c|c|c|c|}
\hline & $\begin{array}{c}\text { linear trend } \\
\text { multiplicative } \\
\text { fluctuations } \\
\text { parameters: } \\
\begin{array}{c}\alpha=0,9 ; \\
\delta=0,1 ; \\
\gamma=0,1\end{array}\end{array}$ & $\begin{array}{c}\text { linear trend } \\
\text { additive fluctua- } \\
\text { tions } \\
\text { parameters: } \\
\alpha=0,9 ; \\
\delta=0,1 ; \\
\gamma=0,1\end{array}$ & $\begin{array}{c}\text { exponential } \\
\text { trend } \\
\text { multiplicative } \\
\text { fluctuations } \\
\text { parameters: } \\
\alpha=0,8 ; \\
\delta=0,1 ; \\
\gamma=0,1\end{array}$ & $\begin{array}{c}\text { exponential } \\
\text { trend } \\
\text { additive fluctua- } \\
\text { tions } \\
\text { parameters: } \\
\alpha=0,9 ; \\
\delta=0,1 ; \\
\gamma=0,1\end{array}$ \\
\hline Average error & 65.95 & 81.66 & -322.14 & -232.30 \\
\hline $\begin{array}{l}\text { Average absolute } \\
\text { error }\end{array}$ & 2680.26 & 2777.35 & 2770.43 & 2843.37 \\
\hline Sum of squares & 887033586 & 929680157 & 900008877 & 954555733 \\
\hline Average square & 13646670 & 14302771 & 13846290 & 14685472 \\
\hline $\begin{array}{l}\text { Average percent. } \\
\text { error }\end{array}$ & -1.75 & -1.39 & -3.06 & -2.47 \\
\hline $\begin{array}{l}\text { Average absolute } \\
\text { percent. error }\end{array}$ & 11.02 & 11.30 & 11.30 & 11.57 \\
\hline
\end{tabular}

\section{Source: Own study.}

${ }^{*} \alpha$ - is a parameter characterizing the smoothing level, it is necessary in all models, $\delta$ - is a parameter of seasonal smoothing and it is defined only when choosing seasonal models, $\gamma$ - is a smoothing parameter of linear and exponential trend, $\varphi$ - parameter defined in case of damped trend

Error analysis shows that the linear trend model with multiplicative fluctuations is the best fitting one. Five of presented errors take minimal values out of four checked models. So to forecast passenger transport in the Rzeszów - Jasionka Airport one shall use a linear trend and multiplicative fluctuations model. Model's equation is as follows:

$$
\begin{gathered}
F_{t-1}=\propto \frac{y_{t-1}}{C_{t-1-r}}+(1-\propto)\left(F_{t-2}-S_{t-2}\right) \\
S_{t-1}=\beta\left(F_{t-1}-F_{t-2}\right)+(1-\beta) S_{t-2}(2) \\
C_{t-1}=\gamma \frac{y_{t-1}}{F_{t-1}}+(1-\gamma) C_{t-1-r}
\end{gathered}
$$

Where:

- equivalent of smoothed value received from simple model of exponential smoothing (average value estimate)

$S_{t-1}$ - estimate of trend increase for a moment or period $t-1$

$C_{t-1}$ - estimate of seasonal factor for a moment or period $t-1$

$\mathrm{r}$ - length of seasonal cycle - number of phases

$\alpha, \gamma, \delta$-parameters of model taking values from interval from [0 to 1].

Forecast equation for a moment or period $\mathrm{t}>\mathrm{n}(\mathrm{n}-$ is number of terms of forecasted variable series) for multiplicative version of model:

$$
y_{t}^{*}=\left[F_{n}+S_{n}(t-n)\right] C_{t-r}(4)
$$

- calculated on the basis of time series by an average of quotients corresponding to the same phase of seasonal cycle, forecasted variable value and smoothed trend value ${ }^{17}$.

\footnotetext{
${ }^{17}$ Prognozowanie gospodarcze metody i zastosowania - praca zbiorowa pod red. Marii Cieślak, Wydawnictwo Naukowe PWN, Warszawa 1997, p. 76
} 
Figure 4. Forecast of passenger transport in the Rzeszów - Jasionka airport from June 2012 to May 2013 by means of exponential smoothing model with linear trend and multiplicative fluctuations

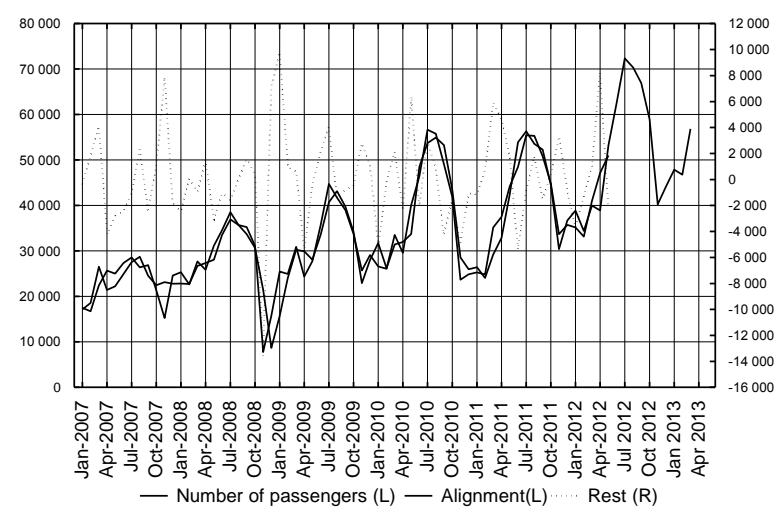

Source: Own study.

Model residuals are characterized with normal distribution $p<\alpha,(p=0,21424)$, so the model is properly estimated.

Figure 5. Normal distribution of model residuals

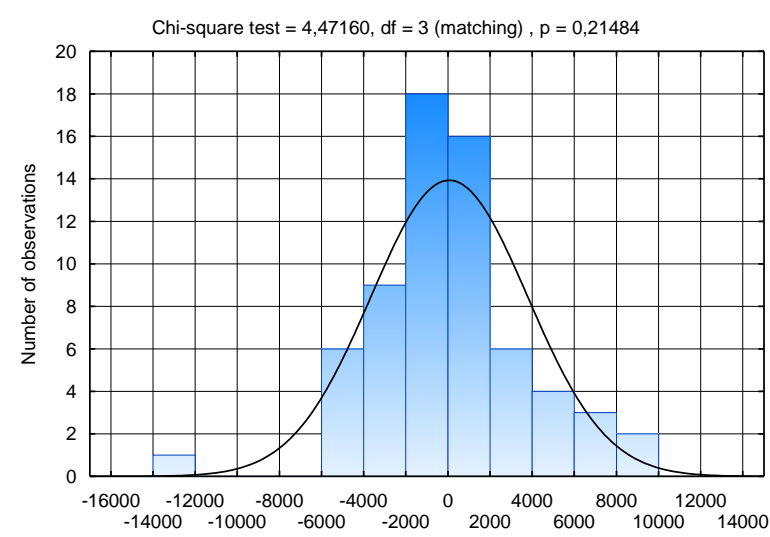

Source: Own study.

Forecast values obtained on the basis of analyzed model are presented in Table 2. 
Table 2. Forecast of passenger transport in the Rzeszów - Jasionka Airport from June 2012 to May 2013

\begin{tabular}{|l|l|l|l|}
\hline Month & Forecast & Month & Forecast \\
\hline June 2012 & 62554.24 & December 2012 & 44151.56 \\
\hline July 2012 & 72356.68 & January 2013 & 47866.03 \\
\hline August 2012 & 70346.90 & February 2013 & 46773.45 \\
\hline September 2012 & 66945.22 & March 2013 & 56850.38 \\
\hline October 2012 & 58942.34 & April 2013 & 54631.49 \\
\hline November 2012 & 40252.76 & May 2013 & 62219.64 \\
\hline
\end{tabular}

Source: Own study.

Results of obtained forecasts keep the tendency and fluctuations of observed series.

\subsection{Forecasts obtained by means of homologous period trend estimation}

Homologous period trend estimation uses relation between observations from different years for the same period. In the researched case months are homologous periods. The procedure is based on estimation of parameters of the analytic trend function separately for each cycle phase. Forecast is set by means of extrapolating the estimated trend function for each cycle phase. Usage of this method forces one to assume the "status quo" rule, i.e. that the observed tendency will retain for each cycle phase. ${ }^{18}$

Each time series relating to particular cycle phase is described with following linear model

$$
y_{i j}=\alpha_{0 i}+\alpha_{1 i} t_{j i}+\xi_{i j}, \quad j=1 \ldots k, \quad i=1 \ldots r
$$

$$
\begin{aligned}
& y_{i j-} \text { value of forecasted variable for the } i \text {-this phase in the } j \text {-this cycle } \\
& t_{i j}-\text { time variable such as } t_{i j}=i+r(j-1) \\
& \alpha_{0 i}, \alpha_{l i}-\text { structural parameters of } i \text {-this model } \\
& \xi \text {-random component }
\end{aligned}
$$

Model parameters are estimated by means of smallest squares method. Due to the fact that analyzed data is of monthly character, 12 linear models were estimated, which will be used for forecasting future values of passenger transport in the Rzeszów - Jasionka Airport.

Table 3. Estimation results of structural parameters of homologous period trend estimations in years 2002-2012

\begin{tabular}{|l|c|c|l|c|c|}
\hline Period & Model equation & $\mathbf{R}^{2}$ & \multicolumn{1}{c|}{ Period } & Model equation & $\mathbf{R}^{2}$ \\
\hline January & $\mathrm{y}^{*}=2815.1 \mathrm{t}+15568$ & 0.809 & July & $\mathrm{y}^{*}=7553.0 \mathrm{t}+21607$ & 0.932 \\
\hline February & $\mathrm{y}^{*}=2298.3 \mathrm{t}+17003$ & 0.807 & August & $\mathrm{y}^{*}=7332.0 \mathrm{t}+21449$ & 0.937 \\
\hline March & $\mathrm{y}^{*}=2866.8 \mathrm{t}+22275$ & 0.947 & September & $\mathrm{y}^{*}=6630.8 \mathrm{t}+19838$ & 0.954 \\
\hline April & $\mathrm{y}^{*}=4691.9 \mathrm{t}+14811$ & 0.849 & October & $\mathrm{y}^{*}=5547.1 \mathrm{t}+18164$ & 0.969 \\
\hline May & $\mathrm{y}^{*}=5845.3 \mathrm{t}+15096$ & 0.951 & November & $\mathrm{y}^{*}=3697.4 \mathrm{t}+11721$ & 0.387 \\
\hline June & $\mathrm{y}^{*}=6008.9 \mathrm{t}+19785$ & 0.956 & December & $\mathrm{y}^{*}=3498.1 \mathrm{t}+15161$ & 0.556 \\
\hline
\end{tabular}

Source: Own study.

\footnotetext{
${ }^{18}$ Radzikowska B., „Metody prognozowania. Zbiór zadań” Uniwersytet Ekonomiczny we Wrocławiu, Wrocław 2004.
} 
The estimated trend functions are quite well matched to the empirical data, which is proved by determination factor $\mathrm{R}^{2}$, the values of which are above $80 \%$. The exception is a trend estimated for months from November 2002 to November 2012, where determination factor was only $39 \%$. It was caused by a very low value of air transport in Jasionka in November 2008. The reason for such low values was the suspension of flights done by one of the key carriers. This value can be considered as outlier, because it differs completely from other values of passenger transport.

Figure 6. Forecast of passenger transport in the Rzeszów - Jasionka Airport from June 2012 to May 2013 by means of homologous period trend estimation

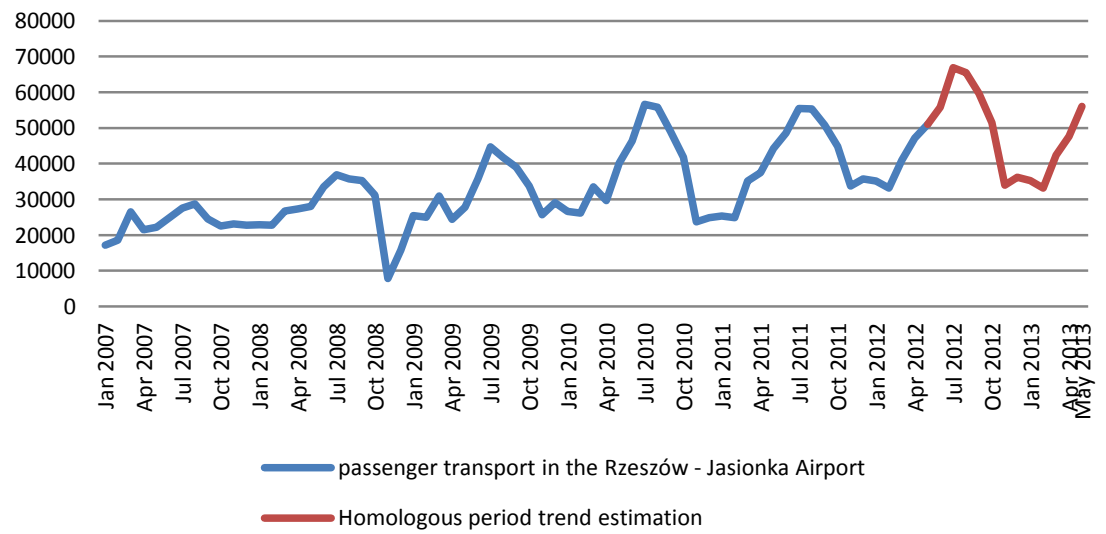

Source: Own study.

Residual distribution obtained for homologous period trend estimation was checked. According to the conducted test the residual distribution is normal $p<\alpha(p=0.35810)$. One can gather that the model is constructed properly.

Figure 7. Residuals distribution of homologous period trend estimation

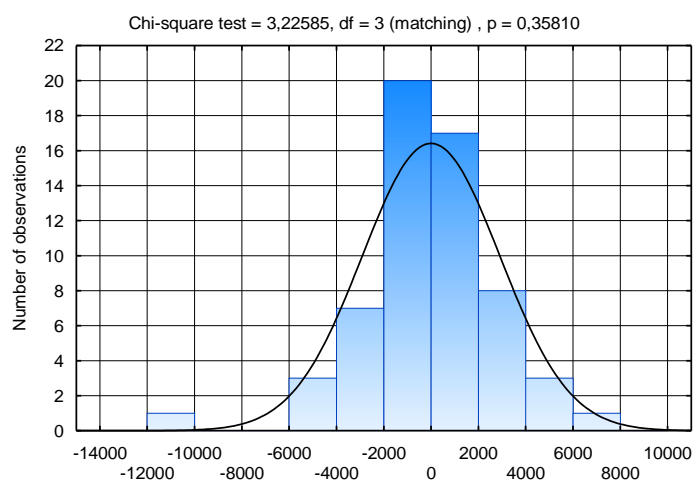

Source: Own study. 
Forecast values obtained on the basis of analyzed model are presented in Table 4.

Table 4. Forecast of passenger transport in the Rzeszów - Jasionka Airport from June 2012 to May 2013

\begin{tabular}{|c|c|c|c|}
\hline Month & Forecast & Month & Forecast \\
\hline June 2012 & 55838.4 & December 2012 & 36149.6 \\
\hline July 2012 & 66925.0 & January 2013 & 35273.7 \\
\hline August 2012 & 65441.0 & February 2013 & 33091.1 \\
\hline September2012 & 59622.8 & March2013 & 42342.6 \\
\hline October 2012 & 51446.6 & April 2013 & 47654.3 \\
\hline November 2012 & 33905.4 & May 2013 & 56013.1 \\
\hline
\end{tabular}

Source: Own study.

Results of obtained forecasts retain tendency and fluctuations of observed series.

\section{SUMMARY}

To construct a forecast two models were used: exponential smoothing - Winters model and homologous period trend estimation. In both instances methods have shown an increase in seasonal fluctuations' amplitudes. An analysis of residuals of constructed models shows that they have normal distribution, which implies correctness of construction of analyzed models. The forecasts obtained with two methods have given similar character of changes, with slightly different levels of volumes of forecasted passenger transport in the Rzeszów - Jasionka Airport. Forecasts to comparison are presented in Figure 8 .

Figure 8. Comparison of forecasts constructed by means of Winters model and homologous period trend estimation

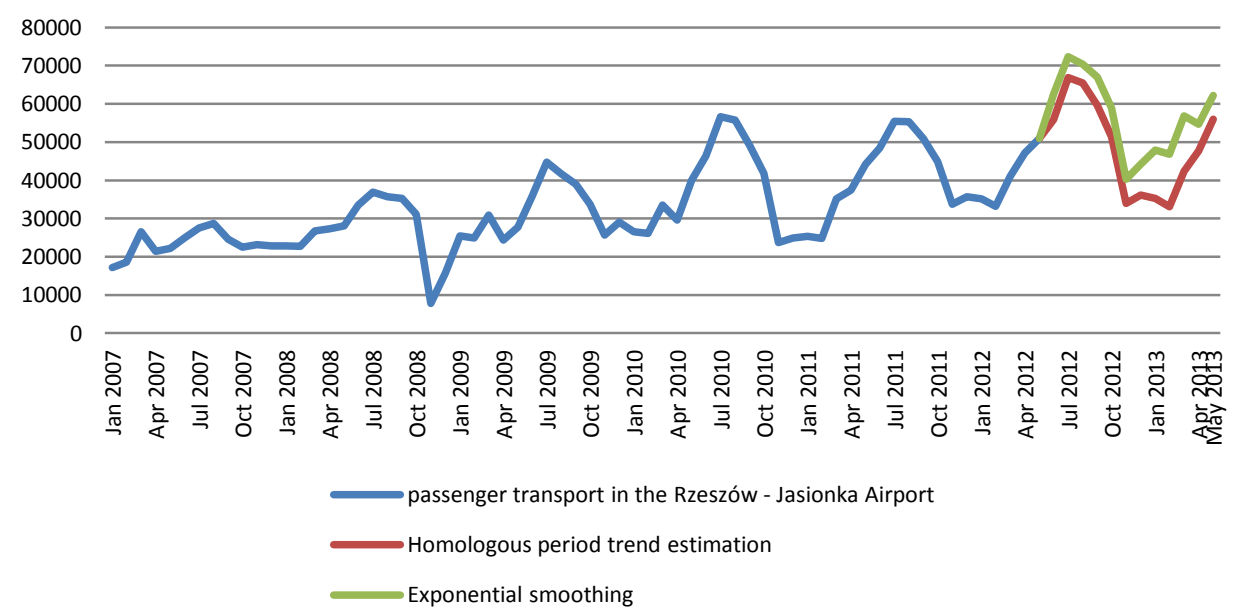

Source: Own study. 
Homologous period trend estimation gives a lower level of forecasted observations and is of more conservative character. The Winters model is expansive. Obtained forecasts should be related to future investments planned for following months closer and further to the environment of analyzed phenomenon. Passenger transport is connected with many factors, which should be taken into account when choosing a proper variant of forecast.

The main leading factors, determining volume of demand for transport in Poland, are: future GDP volume, number of state inhabitants, value and volume of foreign exchange, consumption level, household expenditures structure, rationalization of exploitation factors set for given form of transport, trends for changes in transport and transfer distance influenced by European integration and changes in location of production and settlement in Poland. ${ }^{19}$ So the obtained forecasts should be taken with a pinch of salt and in relation to phenomenon occurring in the economy.

After finishing forecast construction a data from June appeared, so one could execute preliminary evaluation of models and forecasts based on them. Evaluation was made by means of relative error ex post $\Psi$.

Table 5. Factual value of passenger transport in June 2012, forecasts obtained by means of two methods and relative error ex post of estimated forecasts

\begin{tabular}{|l|c|c|c|}
\hline & $\begin{array}{c}\text { Value of passenger transport } \\
\text { (June 2012) }\end{array}$ & $\begin{array}{c}\text { Forecast of } \\
\text { M Winters }\end{array}$ & $\begin{array}{c}\text { Forecast } \\
\text { of TJO }\end{array}$ \\
\hline Factual value & 54468 & 62554.24 & 55838.4 \\
\hline Relative error ex post (\%) & & -14.85 & -2.52 \\
\hline
\end{tabular}

Source: Own study.

Forecasts obtained by means of homologous period trend estimation are undoubtedly less erroneous (circa 2,5\%).

\section{CONCLUSIONS}

Air transport is a vital factor for economic growth, while economic success is a function of availability. The fastest effects are brought by investments in air transport development. Improvement of availability by means of airline network, which is necessary to gain a competitive advantage, should be a strategic goal. Airports stimulate the economic development. "Core cities" near every airport are growing very fast. Air transport is also a catalyst and driving force of innovation development. Cities near airports gain character of key nodes in an economy based on information and knowledge exchange. Access to the global flow of qualified personnel contributes to the exchange of ideas, creates creative synergies, so it is of key importance for the development of a modern economy ${ }^{20}$.

The Rzeszów - Jasionka Airport is developing faster and faster, many investments in air infrastructure are conducted. Situation within the scope of connection infrastructure with airport is much worse. Most of Polish airports do not connect with highways nor

\footnotetext{
${ }^{19}$ Burnewicz J., 'Wizja struktury transportu oraz rozwoju sieci transportowych do roku 2033 ze szczególnym uwzględnieniem docelowej struktury modelowej transportu”, Uniwersytet Gdański Tom II s. 35-36.

${ }^{20}$ Polska 2030 - Wyzwania rozwojowe - wyzwanie 4 - Odpowiedni potencjał infrastruktury, Projekt współfinansowany ze środków Unii Europejskiej w ramach Programu Operacyjnego Pomoc Techniczna, Warszawa 2009, 4 p. 133.
} 
expressways (exceptions are the Katowice-Pyrzowice Airport connected with the S1 expressway and the Kraków-Balice airport connected with the A4 highway). In Poland only the Kraków-Balice Airport has now a railway connection with the city centre (railway stop is located ca. $200 \mathrm{~m}$ from the passenger terminal). ${ }^{21}$ The situation in Jasionka leaves a lot to be desired. Planned investments in the civil aviation sector will allow for the adaptation of Polish airports which are included in the TEN-T network to increasing transport needs and adaptation of infrastructure of air traffic management to dynamically growing traffic in Polish airspace. Elimination of national development barriers by developing road and airport network will increase abilities to use competitive advantages, such as e.g. geographic location. It will also influence the improvement of trade with the European Union countries and other neighbours of Poland. The development of an existing road network will ensure proper service of industry and services and will improve the quality of passenger transport. It will allow also to gain benefits resulting from expansion of Common Market and creation of additional possibilities to attract foreign capital and increasing mobility of people of working age. ${ }^{22}$

Forecasts of the passenger transport in the Rzeszów - Jasionka Airport done with both the first and the second method point to an increasing level of researched phenomenon, so a proper infrastructure should be prepared, one that would allow swift and effective service, as well as ensure comfort for people coming to Podkarpacie.

\section{REFERENCES}

[1] Aczel A.D.(2000),'Statystyka w zarzadzaniu. Wydawnictwo Naukowe PWN, Warszawa

[2] Burnewicz J., 'Wizja struktury transportu oraz rozwoju sieci transportowych do roku 2033 ze szczególnym uwzględnieniem docelowej struktury modelowej transportu”, Uniwersytet Gdański Tom II

[3] Chudy K., Wierzbińska M., 'Zróżnicowanie województw pod względem infrastruktury transportowej w Polsce - wyniki badań”, 2011, Oficyna Wydawnicza Politechniki Rzeszowskiej Zeszyty Naukowe Politechniki Rzeszowskiej, Zarządzanie i Marketing, 2011, z.18,

[4] Gardner E.S. "Exponential smoothing”, The state of the art. Journal of Forecasting 4, 128,1985

[5] Grubb H., Mason A., „Long lead-time forecasting of UK air passengers by Holt-Winters methods with damped trend", International Journal of Forecasting 17 (2001) p.71-82

[6] Radzikowska B., "Metody prognozowania. Zbiór zadań” Uniwersytet Ekonomiczny we Wrocławiu, Wrocław 2004.

[7] Wilecki P.; 'Polskie lotniska czekaja na inwestycje”, Transport i spedycja nr.2 2008

[8] DIAGNOZA POLSKIEGO TRANSPORTU, Stan w 2009 roku, Załącznik 1 do Strategii Rozwoju Transportu, Ministerstwo Infrastruktury, Warszawa 2011

[9] Niebieska księga Nowe wydanie Sektor transportu lotniczego, September 2008

[10] Polska 2030 - Wyzwania rozwojowe - wyzwanie 4 - Odpowiedni potencjał infrastruktury, Projekt współfinansowany ze środków Unii Europejskiej w ramach Programu Operacyjnego Pomoc Techniczna, Warszawa 2009.

[11] Prognozowanie gospodarcze metody i zastosowania - praca zbiorowa pod red. Marii Cieślak, Wydawnictwo Naukowe PWN, Warszawa 1997, p.76

\footnotetext{
${ }^{21}$ DIAGNOZA POLSKIEGO TRANSPORTU, Stan w 2009 roku, Załącznik 1 do Strategii Rozwoju Transportu, Ministerstwo Infrastruktury, Warszawa 2011, p. 17.

${ }^{22}$ Ramowy Program Operacyjny Infrastruktura i środowisko, Narodowe Strategiczne Ramy Odniesienia 20072013 Ministerstwo Rozwoju Regionalnego, Warszawa 2006, p.92
} 
[12] Ramowy Program Operacyjny Infrastruktura i środowisko, Narodowe Strategiczne Ramy Odniesienia 2007-2013 Ministerstwo Rozwoju Regionalnego, Warszawa 2006, p.92

[13] Raport o stanie zagospodarowania przestrzennego województwa podkarpackiego, Część III Infrastruktura Techniczna, Rzeszów 2009, p. 17

[14] Strategia rozwoju transportu do 2020 roku (z perspektywa do 2030 roku) projekt, Ministerstwo Infrastruktury, Warszawa 2011, p.54

\section{KRÓTKOOKRESOWA PROGNOZA PRZEWOZU PASAŻERÓW \\ TRANSPORTEM LOTNICZYM. PORT LOTNICZY RZESZÓW JASIONKA - STUDIUM EMPIRYCZNE}

W ostatnim okresie można zaobserwować znaczny wzrost liczby pasażerów, korzystających z przewozów drogą lotniczą. Nieustanie toczy się także walka konkurencyjna o klienta pomiędzy różnymi liniami lotniczymi w skali całego globu, co powoduje szybki rozwój tej sfery usług. Rynek usług świadczonych w transporcie lotniczym wymaga przeprowadzania ciągłych badań i analiz statystycznych.

Celem artykułu jest próba opracowania prognoz krótkookresowych przewozów pasażerskich drogą lotnicza. Prognoza zostanie opracowana na podstawie szeregu czasowego. Dane obejmują okres od stycznia 2007 roku do maja 2012 roku. Zebrane są w odstępach miesięcznych. Do prognozowania wykorzystano model wygładzania wykładniczego oraz trendów jednoimiennych okresów.

Proces prognozowania i modelowania zostanie przeprowadzony przy użyciu programu Statistica 9.1 .PL.

DOI: 10.7862/rz.2012.zim.15 